\title{
Pengaruh Promosi dan Kualitas Produk terhadap Kepuasan Pelanggan pada UD. Sari Jaya Buah Kabupaten Badung
}

\author{
I Made Adhi Andreanata ${ }^{(1)}$ \\ Ida I Dewa Ayu Yayati Wilyadewi ${ }^{(2)}$ \\ (1)(2) Fakultas Ekonomi Bisnis dan Pariwisata Universitas Hindu Indonesia \\ e-mail:andreanata043@gmail.com
}

\begin{tabular}{|l|l|l|}
\hline Diterima: 2 Desember 2020 & Direvisi: 9 Desember 2020 & Disetujui: 18 Desember 2020 \\
\hline
\end{tabular}

\begin{abstract}
Satisfaction is a feeling of pleasure or disappointment for someone who appears after assessing a product with his hopes. The purpose of this study was to determine the effect of promotion and product quality on customer satisfaction at UD. Sari Jaya Buah, Badung Regency, both racially and simultaneously. This research was conducted at UD. Sari Jaya Buah, Badung Regency. The number of samples was set at 45 respondents using a nonprobability sampling method. The data analysis technique used multiple regression. Based on the results of the analysis found that promotion and product quality have a positive and significant effect on customer satisfaction at UD. Sari Jaya Buah, Badung Regency, both racially and simultaneously. The suggestion in this research is to evaluate other policies and strategies related to Customer Satisfaction, Promotion, and Product Quality
\end{abstract}

Keywords: customer satisfaction, promotion, product quality

\begin{abstract}
ABSTRAK
Kepuasan merupakan perasaan senang atau kecewa seseorang yang muncul setelah melakukan penilaian terhadap suatu produk dengan harapannya. Tujuan penelitian ini adalah untuk mengetahui pengaruh promosi dan kualitas produk terhadap kepuasan pelanggan pada UD. Sari Jaya Buah Kabupaten Badung secara parsial dan simultan. Penelitian ini dilaksanakan pada UD. Sari Jaya Buah Kabupaten Badung. Jumlah sampel ditetapkan sebanyak 45 responden dengan metode non probability sampling. Teknik analisis data menggunakan regresi berganda. Berdasarkan hasil analisis ditemukan bahwa promosi dan kualitas produk berpengaruh positif dan signifikan terhadap kepuasan pelanggan pada UD. Sari Jaya Buah Kabupaten Badung secara parsial dan simultan. Saran dalam penelitian ini adalah melakukan evaluasi terhadap kebijakan dan strategi lainnya terkait kepuasan pelanggan, promosi, dan kualitas produk.
\end{abstract}

Kata kunci: kepuasan pelanggan, promosi, kualitas produk

\section{Pendahuluan}

Komoditi buah menjadi salah satu sektor yang sangat baik untuk dijadikan lading usaha.

Iklim tropis yang baik serta banyaknya jenis buah yang tumbuh di Indonesia menjadi salah satu 
modal awal untuk menjalankan usaha ini. Tentunya, untuk mampu bersaing dalam dunia bisnis, perusahaan harus mampu memberikan kepuasan kepada para pelanggannya gar bisnis bisa berjalan secara berkelanjutan.

Kepuasan pelanggan adalah perasaan senang atau kecewa seseorang yang muncul setelah membandingkan antara persepsi atau kesannya terhadap kinerja (hasil) suatu produk dan harapanharapannya (Faradina dkk, 2016). Menurut Afnina dan Hastuti (2018), kepuasan pelanggan adalah respon pelanggan terhadap evaluasi ketidaksesuaian atau diskonfirmasi yang dirasakan antara harapan sebelumnya dan kinerja actual produk yang dirasakan setelah pemakaian. Menurut Lensun, dkk (2014) faktor-faktor yang mempengaruhi kepuasan pelanggan adalah kualitas produk, harga dan promosi.

Promosi menjadi salah satu faktor yang memberikan pengaruh terhadap kepuasan pelanggan. Promosi adalah mengkomunikasikan informasi antara penjual dan pembeli potensial atau orang lain untuk mempengaruhi sikap dan perilaku (Cannon, 2008 dalam Faradina dkk, 2016). Menurut Faradina, dkk (2016) promosi adalah aktivitas pemasaran yang perusahaan menyebarkan informasi, mempengaruhi atau membujuk, dan mengingatkan pasar sasaran atas perusahaan yang bersangkutan. Hasil penelitian yang dilakukan oleh Faradina, dkk (2016) serta Handoko (2017), menunjukkan adanya pengaruh promosi terhadap kepuasan pelanggan.

Faktor lain yang dapat mempengaruhi kepuasan pelanggan adalah kualitas produk yang ditawarkan perusahaan. Kualitas produk adalah kemampuan sebuah produk dalam memperagakan fungsinya, hal itu termasuk keseluruhandurabilitas, reliabilitas, ketepatan, kemudahan pengoperasian dan reparasi produk juga atribut produk lainnya (Lenzun dkk, 2014). Penelitian yang dilakukan oleh Lenzun, dkk (2014) serta Razak (2019) dan Premayani dan Yoga (2019) menunjukkan adanya pengaruh positif dan signifikan antara variabel kualitas produk dan kepuasan pelanggan.

UD. Sari Jaya Buah merupakan salah satu supplier buah dan sayur yang menyediakan bermacam-macam jenis buah dan sayur di Kabupaten Badung Bali. UD Sari Jaya Buah sebagai pengembang tidak hanya sebatas memproduksi saja, akan tetapi berusaha menarik konsumen dan mempengaruhi tingkah laku konsumen untuk membeli produk yang ditawarkan. Setidaknya ada 25 pengembang lain yang menjalani usaha supplier buah dan sayur di Kabupaten Badung sehingga persaingan bisnis menjadi semakin ketat.

Berdasarakan data, pada tahun 2018 jumlah penjualan dari tahun sebelumnya mengalami peningkatan yang signifikan sedangkan jumlah penjualan tahun 2019 mengalami penurunan jumlah penjualan. Hal ini disebabkan oleh masih kurangnya promosi yang dilakukan seperti 
kegiatan pameran, pemberian potongan harga, dan lain-lain. Biaya promosi yang tinggi pada tahun 2019 dirasa masih belum optimal pengeluarannya dikarenakan peningkatan harga jual yang tinggi menyebabkan penjualan pada tahun 2019 mengalami penurunan dibandingkan tahun sebelumnya.

Pelaksanaan promosi yang tepat sasaran dan kualitas produk yang baik menjadi salah satu strategi yang bisa digunkan perusahaan unuk meningkatkan daya saing. Tujuan penelitian ini adalah (1) mengetahui pengaruh promosi terhadap kepuasan pelanggan, (2) mengetahui pengaruh kualitas prosuk terhadap kepuasan pelanggan, dan (3) mengetahui pengaruh promosi dan kualitas produk terhadap kepuasan pelanggan.

\section{Telaah Literatur dan Kajian Pustaka}

\section{Kepuasan Pelanggan}

Afnina dan Hastuti (2018) menyatakan, kepuasan pelanggan adalah respon pelanggan terhadap evaluasi ketidaksesuaian atau diskonfirmasi yang dirasakan antara harapan sebelumnya dan kinerja actual produk yang dirasakan setelah pemakaian. Menurut Tjiptono (2008:258) kepuasan pelanggan diukur dengan menggunakan beberapa indikator pengukuran diantaranya (1) Harapan, (2) Kepuasan, (3) Manfaat, (4) Harga, dan (5) Kualitas Produk.

\section{Promosi}

Promosi merupakan suatu bidang kegiatan marketing dan merupakan komunikasi yang dilaksanakan perusahaan kepada pembeli atau konsumen yang memuat pemberitaan, membujuk dan mempengaruhi (Handoko, 2017). Menurut Kotler (2010) promosi dapat diukur dengan beberapa indikator pengukuran yaitu (1) Periklanan, (2) Promosi penjualan, (3) Hubungan masyaraka dan publisitis, dan (4) Personal Selling.

\section{Kualitas Produk}

Kualitas produk adalah kemampuan sebuah produk dalam memperagakan fungsinya, hal itu termasuk keseluruhan durabilitas, reliabilitas, ketepatan, kemudahan pengoperasian dan reparasi produk juga atribut produk lainnya (Lenzun dkk, 2014). Menurut Menurut Kotler dan Keller (2009:145) menyebutkan terdapat tiga indikator yang digunakan untuk mengukur kualitas produk, diantaranya (1) Kualitas, (2) Kemasan produk, dan (3) Karakteristik.

H1. Diduga promosi berpengaruh positif dan signifikan terhadap kepuasan pelanggan pada UD. Sari Jaya Buah.

H2. Diduga kualitas produk berpengaruh positif dan signifikan terhadap kepuasan pelanggan pada UD. Sari Jaya Buah.

H3. Diduga promosi dan kualitas produk berpengaruh positif dan signifikan terhadap kepuasan pelanggan pada UD. Sari Jaya Buah. 


\section{Metode Penelitian}

Penelitian ini termasuk dalam jenis penelitian asosiatif atau penelitian yang bertujuan untuk menguji pengaruh satu variabel atau lebih. Desain penelitian ini adalah pengaruh promosi dan kualitas produk terhadap kepuasan pelanggan pada UD. Sari Jaya Buah. Populasi dalam penelitian ini adalah seluruh penentu keputusan pada 15 toko buah langganan yaitu sebanyak 45 orang. Metode penentuan sampel yang digunakan dalam penelitian ini, yaitu non probability sampling karena seluruh anggota populasi dilibatkan dalam penelitian.

Metode yang digunakan untuk mengumpulkan data antara lain observasi, wawancara, studi pustaka, dan kusioner. Skala pengukuran yang digunakan dalam kuisioner adalah skala likert dengan lima pilihan jawaban yang terdiri atas jawaban sangat setuju diberi skor 5, jawaban setuju diberi skor 4, jawaban cukup setuju diberi skor 3, jawaban tidak setuju diberi skor 2, dan jawaban sangat tidak setuju diberi skor 1. Teknik analisis data yang digunakan dalam penelitian ini adalah analisis regresi linear berganda yang akan dikerjakan dengan menggunakan program SPSS (Statistical Package for the Social Sciences). Teknik analisis data ini bertujuan agar data yang diperoleh tersebut benar - benar handal, sehingga dapat dipertanggung jawabkan kebenarannya.

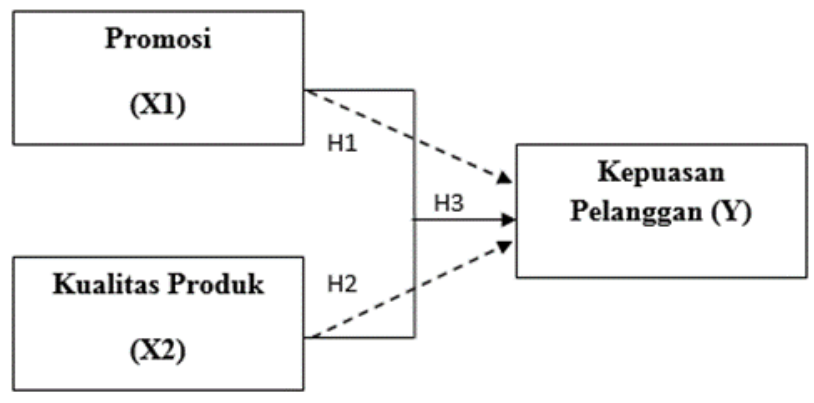

\section{Gambar 1. Kerangka Berpikir}

\section{Hasil Penelitian dan Pembahasan}

Tabel 1 menunjukkan bahwa seluruh instrumen penelitian variabel Promosi (X1), Kualitas Produk (X2), dan Kepuasan Pelanggan (Y) seluruhnya adalah valid karena semua instrumen penelitian memiliki koefisien korelasi pearson product moment $(\mathrm{r})>0,3$ dan reliabel karena semua instrumen penelitian memiliki koefisien cronbach's alpha $(\alpha)$ lebih dari 0,6.

Dalam penelitian ini karakteristik responden digambarkan mengenai jenis kelamin dan umur. Adapun karakteristik yang terkumpul melalui pengumpulan kuesioner dapat dilihat pada Tabel 2. Dilihat dari jenis kelamin, dapat dinyatakan bahwa responden didominasi oleh perempuan yaitu sebanyak25 orang $(55,56 \%)$ sedangkan responden laki-laki adalah sebanyak 20 orang 
$(44,44 \%)$. Dilihat dari usia, dapat dinyatakan bahwa responden tertinggi memiliki rentang usia 2630 Tahun sebanyak 13 orang $(28,89 \%)$ sedangkan responden terendah berada pada rentang usia < 35 Tahun sebanyak 9 orang $(20,00 \%)$. Hal ini mengindikasikan bahwa nasabah cenderung dalam usia produktif.

Table 1 Hasil Uji Validitas dan Reliabilitas

\begin{tabular}{|c|c|c|c|c|c|}
\hline Variabel & $\begin{array}{c}\text { Item } \\
\text { Pertanyaan }\end{array}$ & $\begin{array}{c}\text { Koefisien } \\
\text { Korelasi }\end{array}$ & Keterangan & $\begin{array}{l}\text { Cronbach } \\
\text { Alpha }\end{array}$ & Keterangan \\
\hline \multirow{4}{*}{ Promosi $\left(\mathrm{X}_{1}\right)$} & $\mathrm{P} 1$ & 0,791 & Valid & \multirow{4}{*}{0,901} & \multirow{4}{*}{ Reliabel } \\
\hline & $\mathrm{P} 2$ & 0,835 & Valid & & \\
\hline & P3 & 0,942 & Valid & & \\
\hline & $\mathrm{P} 4$ & 0,930 & Valid & & \\
\hline \multirow{3}{*}{$\begin{array}{c}\text { Kualitas } \\
\text { Produk }\left(\mathrm{X}_{2}\right)\end{array}$} & $\mathrm{P} 1$ & 0,901 & Valid & \multirow{3}{*}{0,804} & \multirow{3}{*}{ Reliabel } \\
\hline & $\mathrm{P} 2$ & 0,815 & Valid & & \\
\hline & $\mathrm{P} 3$ & 0,841 & Valid & & \\
\hline \multirow{5}{*}{$\begin{array}{c}\text { Kepuasan } \\
\text { Pelanggan (Y) }\end{array}$} & P1 & 0,811 & Valid & \multirow{5}{*}{0,828} & \multirow{5}{*}{ Reliabel } \\
\hline & $\mathrm{P} 2$ & 0,754 & Valid & & \\
\hline & P3 & 0,905 & Valid & & \\
\hline & $\mathrm{P} 4$ & 0,705 & Valid & & \\
\hline & P5 & 0,571 & Valid & & \\
\hline
\end{tabular}

Sumber: Data diolah, 2020

Tabel 2 Karakteristik Responden

\begin{tabular}{cccc}
\hline Karkteristik & Keterangan & Jumlah (orang) & Persentase (\%) \\
\hline \multirow{3}{*}{ Jenis Kelamin } & Laki-laki & 20 & 44,44 \\
& Perempuan & 25 & 55,56 \\
& Total & 45 & 100 \\
\hline \multirow{2}{*}{ Umur } & $21-25$ & 11 & 24,44 \\
& $26-30$ & 13 & 28,89 \\
& $30-35$ & 12 & 26,67 \\
& $>35$ & 9 & 20,00 \\
\hline
\end{tabular}

Sumber: Data diolah, 2020

Deskripsi Jawaban Responden

Berdasarkan jawaban responden pada Tabel 3 diketahui persepsi responden mengenai kepuasan pelanggan pada UD. Sari Jaya Buah adalah baik dengan nilai rata - rata secara keseluruhan sebesar 3,42. Hal ini berarti UD. Sari Jaya Buah telah mampu menciptakan kepuasan pelanggan dengan baik. Berdasarkan jawaban responden pada Tabel 4 diketahui persepsi responden mengenai promosi pada UD. Sari Jaya Buah adalah kurang baik dengan nilai rata - rata secara keseluruhan sebesar 3,32. Hal ini berarti UD. Sari Jaya Buah belum mampu melaksanakan promosi dengan baik. Berdasarkan jawaban responden pada Tabel 5 diketahui persepsi responden mengenai kualitas produk pada UD. Sari Jaya Buah adalah kurang baik dengan nilai rata - rata secara keseluruhan sebesar 3,4. Hal ini berarti UD. Sari Jaya Buah belum mampu memberikan kualitas produk yang baik. 
Tabel 3 Jawaban Responden Tentang Kepuasan Pelanggan

\begin{tabular}{|c|c|c|c|c|c|c|c|c|}
\hline \multirow[t]{2}{*}{ Pernyataan } & \multicolumn{5}{|c|}{$\begin{array}{c}\text { Jawaban } \\
\text { Responden }\end{array}$} & \multirow{2}{*}{$\begin{array}{l}\text { Jumlah } \\
\text { Skor }\end{array}$} & \multirow{2}{*}{$\begin{array}{l}\text { Rata- } \\
\text { Rata } \\
\text { Skor }\end{array}$} & \multirow[t]{2}{*}{ Keterangan } \\
\hline & 5 & 4 & 3 & 2 & 1 & & & \\
\hline $\begin{array}{l}\text { Konsumen akan loyal untuk berbelanja di } \\
\text { Sari Jaya Buah. }\end{array}$ & 2 & 19 & 10 & 14 & 0 & 144 & 3,20 & $\begin{array}{c}\text { Kurang } \\
\text { Baik }\end{array}$ \\
\hline $\begin{array}{l}\text { Konsumen merasa puas setelah berbelanja } \\
\text { di Sari Jaya Buah. }\end{array}$ & 5 & 16 & 19 & 5 & 0 & 159 & 3,53 & Baik \\
\hline $\begin{array}{l}\text { Konsumen memperoleh barang yang } \\
\text { diperlukan dengan harga terjangkau namun } \\
\text { dengan kualitas baik. }\end{array}$ & 2 & 24 & 6 & 9 & 4 & 146 & 3,24 & $\begin{array}{c}\text { Kurang } \\
\text { Baik }\end{array}$ \\
\hline $\begin{array}{l}\text { Harga produk yang dijual Sari Jaya Buah } \\
\text { terjangkau dan rasional. }\end{array}$ & 8 & 16 & 18 & 3 & 0 & 164 & 3,64 & Baik \\
\hline $\begin{array}{l}\text { Kualitas produk yang dijual Sari Jaya Buah } \\
\text { sesuai dengan harga yang dipasarkan. }\end{array}$ & 2 & 26 & 10 & 7 & 0 & 158 & 3,51 & Baik \\
\hline Rata-R & A & & & & & & 3,42 & Baik \\
\hline
\end{tabular}

Sumber: Data diolah, 2020

\section{Tabel 4 Jawaban Responden Tentang Promosi}

\begin{tabular}{|c|c|c|c|c|c|c|c|c|}
\hline \multirow[t]{2}{*}{ Pernyataan } & \multicolumn{5}{|c|}{$\begin{array}{c}\text { Jawaban } \\
\text { Responden }\end{array}$} & \multirow{2}{*}{$\begin{array}{c}\text { Jumlah } \\
\text { Skor }\end{array}$} & \multirow{2}{*}{$\begin{array}{l}\text { Rata- } \\
\text { Rata } \\
\text { Skor }\end{array}$} & \multirow[t]{2}{*}{ Keterangan } \\
\hline & 5 & 4 & 3 & 2 & 1 & & & \\
\hline $\begin{array}{l}\text { UD. Sari Jaya Buah memasarkan } \\
\text { produknya secara langsung maupun melalui } \\
\text { media massa. }\end{array}$ & 5 & 20 & 8 & 12 & 0 & 153 & 3,40 & Kurang Baik \\
\hline $\begin{array}{l}\text { UD. Sari Jaya Buah mempunyai promosi } \\
\text { potongan harga untuk pembelanjaan dalam } \\
\text { jumlah tertentu. }\end{array}$ & 3 & 26 & 7 & 9 & 0 & 158 & 3,51 & Baik \\
\hline $\begin{array}{l}\text { Promosi yang dilakukan UD. Sari Jaya } \\
\text { Buah membuat masyarakat tertarik untuk } \\
\text { berbelanja. }\end{array}$ & 2 & 21 & 6 & 13 & 3 & 141 & 3,13 & Kurang Baik \\
\hline $\begin{array}{l}\text { Promosi yang dilakukan UD. Sari Jaya } \\
\text { Buah dilakukan secara langsung dengan } \\
\text { pembeli. }\end{array}$ & 5 & 18 & 9 & 10 & 3 & 147 & 3,26 & Kurang Baik \\
\hline \multicolumn{7}{|c|}{ Rata-Rata Skor } & 3,32 & Kurang Baik \\
\hline
\end{tabular}

Sumber: Data diolah, 2020

\section{Tabel 5 Jawaban Responden Tentang Kepuasan Pelanggan}

\begin{tabular}{|c|c|c|c|c|c|c|c|c|}
\hline \multirow[t]{2}{*}{ Pernyataan } & \multicolumn{5}{|c|}{$\begin{array}{l}\text { Jawaban } \\
\text { Responden }\end{array}$} & \multirow{2}{*}{$\begin{array}{l}\text { Jumlah } \\
\text { Skor }\end{array}$} & \multirow{2}{*}{$\begin{array}{l}\text { Rata-Rata } \\
\text { Skor }\end{array}$} & \multirow[t]{2}{*}{ Keterangan } \\
\hline & 5 & 4 & 3 & 2 & 1 & & & \\
\hline $\begin{array}{l}\text { Kualitas produk yang dijual Sari Jaya Buah } \\
\text { baik dan bagus. }\end{array}$ & 4 & 20 & 16 & 5 & 0 & 158 & 3,51 & Baik \\
\hline $\begin{array}{l}\text { Kemasan produk yang dijual Sari Jaya Buah } \\
\text { higienis dan bersih. }\end{array}$ & 4 & 21 & 12 & 8 & 0 & 156 & 3,46 & Baik \\
\hline $\begin{array}{l}\text { Produk yang dijual Sari Jaya Buah selalu } \\
\text { segar dan bebas bahan kimia }\end{array}$ & 1 & 23 & 8 & 11 & 2 & 145 & 3,22 & $\begin{array}{l}\text { Kurang } \\
\text { Baik }\end{array}$ \\
\hline \multicolumn{7}{|c|}{ Rata-Rata Skor } & 3,40 & Kurang Baik \\
\hline
\end{tabular}

Sumber: Data diolah, 2020

Uji Asumsi Klasik 
Berdasarkan Tabel 6 nilai Asymp. Sig. (2-tailed) = 0,200. Nilai Sig. > 0,05 sehingga dapat disimpulkan seluruh data berdistribusi normal. Berdasarkan Tabel 7 bahwa nilai tolerance masingmasing variabel lebih besar dari 0,10 dan nilai VIF lebih kecil dari 10, maka dapat disimpulkan tidak terjadi multikolinearitas atau tidak terjadi korelasi diantara variabel Promosi (X1) dan Kualitas Produk (X2). Berdasarkan Tabel 8 dijelaskan bahwa nilai signifikansi masing - masing variabel bebas dari Promosi (X1) dan Kualitas Produk (X2) lebih dari alpha sebesar 0,05. Hal ini dapat disimpulkan bahwa tidak terjadi heteroskedastisitas pada model regresi.

\section{Tabel 6 Hasil Uji Normalitas}

\begin{tabular}{llr}
\hline & & Unstandardized Residual \\
\hline $\mathrm{N}$ & & 45 \\
Normal Parameters ${ }^{\mathrm{a}, \mathrm{b}}$ & Mean & .0000000 \\
& Std. Deviation & 1.42888200 \\
Most Extreme Differences & Absolute & .092 \\
& Positive & .092 \\
Test Statistic & Negative & -.091 \\
Asymp. Sig. (2-tailed) & & .092 \\
Sumber: & & $.200^{\mathrm{c}, \mathrm{d}}$ \\
\hline
\end{tabular}

Sumber : data diolah, 2020

Tabel 7 Hasil Uji Multikolinearitas

\begin{tabular}{lccc}
\hline \multirow{2}{*}{ Variabel } & \multicolumn{2}{c}{ Colinearity Statistic } & Keterangan \\
\cline { 2 - 3 } & Tolerance & VIF & \\
\hline Promosi $\left(\mathrm{X}_{1}\right)$ & 0,366 & 2,736 & Non Multikolinearitas \\
Kualitas Produk $(\mathrm{X} 2)$ & 0,367 & 2,737 & Non Multikolinearitas \\
\hline
\end{tabular}

Sumber : data diolah, 2020

\section{Tabel 8 Hasil Uji Heteroskedastisitas}

\begin{tabular}{|c|c|c|c|c|c|}
\hline \multirow{2}{*}{ Model } & \multicolumn{2}{|c|}{ Unstandardized Coefficients } & \multirow{2}{*}{$\begin{array}{c}\text { Standardized Coefficients } \\
\text { Beta }\end{array}$} & \multirow{2}{*}{$\mathrm{T}$} & \multirow{2}{*}{ Sig. } \\
\hline & $\mathrm{B}$ & Std. Error & & & \\
\hline (Constant) & 1.035 & .647 & & 1.599 & .117 \\
\hline $\mathrm{X} 1$ & .067 & .063 & .266 & 1.057 & .296 \\
\hline $\mathrm{X} 2$ & -.084 & .102 & -.205 & -.816 & .419 \\
\hline
\end{tabular}

Sumber : data diolah, 2020

Analisis Regresi Linear Berganda

Analisis ini digunakan untuk mengetahui besarnya pengaruh secara simultan antara Promosi dan Kualitas Produk terhadap Kepuasan Pelanggan. Regresi linier berganda dinyatakan dalam bentuk persamaan garis regresi linier berganda yaitu $\hat{Y}=\beta 0+\beta 1 . X 1+\beta 2 . X 2+\varepsilon i$.

Tabel 9 Hasil Analisis Regresi linear Berganda

\begin{tabular}{|c|c|c|c|c|c|}
\hline \multirow{2}{*}{ Model } & \multicolumn{2}{|c|}{ Unstandardized Coefficients } & \multirow{2}{*}{$\begin{array}{c}\text { Standardized Coefficients } \\
\text { Beta }\end{array}$} & \multirow{2}{*}{$\mathrm{T}$} & \multirow{2}{*}{ Sig. } \\
\hline & $\mathrm{B}$ & Std. Error & & & \\
\hline (Constant) & 2.169 & 1.001 & & 2.167 & .036 \\
\hline $\mathrm{X} 1$ & .265 & .098 & .329 & 2.712 & .010 \\
\hline $\mathrm{X} 2$ & .779 & .158 & .596 & 4.916 & .000 \\
\hline
\end{tabular}

Sumber : data diolah, 2020 
Berdasarkan nilai $\alpha$, b1,dan b2 diperoleh persamaan garis regresi linier berganda antara Promosi dan Kualitas Produk terhadap Kepuasan Pelanggan yaitu $\hat{Y}=2,169+0,265$ X1 + 0,779 $\mathrm{X} 2$ dan memberikan informasi bahwa $\alpha=2,169$, secara statistik menunjukan bahwa minat nasabah akan tetap sebesar 2,169 dengan syarat variabel lain dalam penelitian ini yakni Promosi (X1) dan Kualitas Produk (X2) diasumsikan sama dengan nol. $\beta 1=0,265$, secara statistik menunjukkan setiap terjadi (adanya) peningkatan promosi sebesar satu satuan maka akan menyebabkan meningkatanya kepuasan pelanggan sebesar 0,265 dengan syarat variabel lain diasumsikan sama dengan nol. $\beta 2=0,779$, secara statistik menunjukkan setiap terjadi (adanya) peningkatan kualitas produk sebesar satu satuan maka akan menyebabkan meningkatanya Minat nasabah sebesar 0,779 dengan syarat variabel lain diasumsikan sama dengan nol.

Berdasarkan Tabel 10, dikemukakan bahwa koefisien determinasi yang ditunjukkan dari nilai R Square sebesar 0,775, hal ini berarti variabel dependen Kepuasan Pelanggan (Y) dapat dijelaskan oleh dua variabel independen yaitu Promosi (X1) dan Kualitas Produk (X2) sebesar $77,5 \%$ sedangkan sisanya 0,225 atau $22,50 \%$ dijelaskan oleh variabel atau sebab - sebab lainnya di luar model penelitian.

\section{Tabel 10 Hasil Analisis Koefisien Determinasi $\left(\mathbf{R}^{2}\right)$}

\begin{tabular}{ccccc}
\hline Model & R & R Square & Adjusted R Square & Std. Error of the Estimate \\
\hline 1 & $.880^{\mathrm{a}}$ & .775 & .764 & 1.46251 \\
\hline
\end{tabular}

Sumber: Data diolah, 2020

Uji statistik $t$ pada dasarnya menunjukkan seberapa jauh pengaruh satu variabel penjelas/independen digunakan untuk menguji masing-masing hipotesis $\mathrm{H} 1$, dan $\mathrm{H} 2$ yaitu secara parsial variabel Promosi (X1) dan Kualitas Produk (X2) terhadap Kepuasan Pelanggan (Y) adalah memang nyata terjadi (signifikan) atau hanya diperoleh secara kebetulan.

\section{Tabel 11. Hasil Uji-T}

\begin{tabular}{|c|c|c|c|c|c|}
\hline \multirow{2}{*}{ Model } & \multicolumn{2}{|c|}{ Unstandardized Coefficients } & \multirow{2}{*}{$\begin{array}{c}\text { Standardized Coefficients } \\
\text { Beta } \\
\end{array}$} & \multirow{2}{*}{$\mathrm{T}$} & \multirow{2}{*}{ Sig. } \\
\hline & $\mathrm{B}$ & Std. Error & & & \\
\hline (Constant) & 2.169 & 1.001 & & 2.167 & .036 \\
\hline $\mathrm{X} 1$ & .265 & .098 & .329 & 2.712 & .010 \\
\hline $\mathrm{X} 2$ & .779 & .158 & .596 & 4.916 & .000 \\
\hline
\end{tabular}

Sumber: Data diolah, 2020

1. Pengaruh Promosi Terhadap Kepuasan Pelanggan Pada UD. Sari jaya Buah Kabupaten Badung.

Berdasarkan hasil perhitungan, maka diperoleh nilai t-hitung untuk variabel promosi sebesar 2,712 lebih besar dibandingkan dengan nilai t-tabel sebesar 1,683 dengan signifikansi 0,010 yang lebih kecil dari $\alpha$ (taraf nyata) $=0,05$ berada pada daerah penolakan Ho, yang berarti Ho ditolak dan H1 diterima. Artinya bahwa secara parsial promosi berpengaruh positif dan I Made Adhi Andreanata dan Ida I Dewa Ayu Yayati Wilyadewi | 21 
signifikan terhadap kepuasan pelanggan UD. Sari Jaya Buah Kabupaten Badung. Hasil penelitian ini juga didukung oleh hasil penelitian yang dilakukan oleh Lenzun, dkk (2014), yang menyatakan bahwa promosi berpengaruh positif dan signifikan terhadap kepuasan pelanggan.

2. Pengaruh Kualitas Produk Terhadap Kepuasan Pelanggan Pada UD. Sari jaya Buah Kabupaten Badung.

Berdasarkan hasil perhitungan, maka diperoleh nilai t-hitung untuk variabel kualitas produk sebesar 4,916 lebih besar dibandingkan dengan nilai t-tabel sebesar 1,683 dengan signifikansi 0,000 yang lebih kecil dari $\alpha$ (taraf nyata) $=0,05$ berada pada daerah penolakan Ho, yang berarti Ho ditolak dan $\mathrm{H} 2$ diterima. Artinya bahwa secara parsial kualitas produk berpengaruh positif dan signifikan terhadap kepuasan pelanggan UD. Sari Jaya Buah Kabupaten Badung. Hasil penelitian ini juga didukung oleh hasil penelitian yang dilakukan oleh Christian (2013) serta Frenky (2013) yang menyatakan bahwa kualitas produk berpengaruh positif dan signifikan terhadap kepuasan pelanggan.

Berdasarkan Tabel 12, dikemukakan bahwa nilai F-test 72,172 lebih besar daripada F-tabel 2,83 dengan signifikansi 0,000 lebih kecil dari $(\alpha)=0,05$ berada pada daerah penolakan Ho, maka Ho ditolak atau Hi diterima. Artinya memang benar secara simultan ada pengaruh yang positif dan signifikan antara promosi dan kualitas produk terhadap kepuasan pelanggan UD. Sari Jaya Buah Kabupaten Badung.

\section{Tabel 12 Hasil Uji-F}

\begin{tabular}{llrcccc}
\hline \multicolumn{1}{c}{ Model } & Sum of Square & df & Mean Square & F & Sig. \\
\hline \multirow{2}{*}{1} & Regression & 308.743 & 2 & 154.371 & 72.172 & $.000^{\mathrm{b}}$ \\
Residual & 89.835 & 42 & 2.139 & & \\
Total & 398.578 & 44 & & & \\
\hline
\end{tabular}

Sumber: data diolah, 2020

\section{Simpulan}

Berdasarkan data yang diperoleh dari hasil analisis dapat ditarik kesimpulan bahwa, promosi berpengaruh positif dan signifikan terhadap kepuasan pelanggan UD. Sari Jaya Buah. Pernyataan tersebut mengisyaratkan bahwa promosi dapat meningkatkan kepuasan pelanggan UD. Sari Jaya Buah. Hasil mengindikasikan bahwa semakin baik promosi maka kepuasan pelanggan UD. Sari Jaya Buah akan meningkat. Kualitas produk berpengaruh positif dan signifikan terhadap kepuasan pelanggan UD. Sari Jaya Buah. Pernyataan tersebut mengisyaratkan bahwa kualitas produk dapat meningkatkan kepuasan pelanggan UD. Sari Jaya Buah karena produk-produk yang dijual memiliki kualitas yang baik dan bagus. Hasil mengindikasikan bahwa semakin baik dan mendukung kualitas produk, maka semakin tinggi pula kepuasan pelanggan UD. Sari Jaya Buah. 
Promosi dan kualitas produk berpengaruh positif dan signifikan terhadap kepuasan pelanggan UD.

Sari Jaya Buah. Pernyataan tersebut mengisyaratkan bahwa promosi dan kualitas produk secara bersama-sama dapat meningkatan kepuasan pelanggan UD. Sari Jaya Buah. Hal ini mengindikasikan bahwa semakin baik dan mendukungnya promosi dan kualitas produk maka nantinya akan meningkatkan kepuasan pelanggan pada UD. Sari Jaya Buah.

Berdasarkan uraian kesimpulan tersebut di atas, dapat disarankan sebagai berikut, terkait dengan promosi, perusahaan perlu melakukan promosi secara intensif, baik dengan promosi ke perumahan disekitar lokasi usaha, promosi melalui sosial media, memberikan potongan harga serta memberikan kartu member bagi konsumen yang sering berbelanja. Terkait dengan kualitas produk, perusahaan perlu untuk menjaga kualitas produk yang diambil dari petani dan meningkatkan pengawasan saat pengemasan hingga ke tangan konsumen. Terkait dengan kepuasan konsumen, perusahaan perlu untuk memberikan pelayanan yang terbaik, respon yang tanggap ketika konsumen memerlukan sesuatu, dan membuat suasana toko nyaman sehingga konsumen puas berbelanja. Bagi peneliti selanjutnya agar dapat meneliti dan mengkaji lebih dalam faktor-faktor lain yang tidak diteliti dalam penelitian ini yang dapat mempengaruhi kepuasan pelanggan selain promosi dan kualitas produk. Agar nantinya dapat mengetahui tindakan apa yang harus dilakukan dalam meningkatkan kepuasan pelanggan.

\section{Daftar Pustaka}

Afnina, Hastuti Yulia. 2018. Pengaruh Kualitas Produk Terhadap kepuasan Pelanggan. Jurnal Samudra Ekonomi dan Bisnis. Vol 9, No.1 Januari 2018. ISSN: 2089-1989. ISSP: 26141523.

Andini p. farrah. 2013. Analisis Pengaruh Suasana Toko, Kualitas Produk dan Kepuasan Pelanggan Terhadap Loyalitas Pelanggan (Studi Kasus Pada Konsumen Distro Deep Store di Surakarta. Skripsi Fakultas Ekonomika dan Bisnis Universitas Diponogoro Semarang.

Ardhana, Oldy. 201. Analisis Pengaruh Kualitas Pelayamam, Harga dan Lokasi Terhadap Kepuasan Pelanggan. Skripsi Fakultas Ekonomi Universitas Diponogoro Semarang.

Bilson, Simamora. 2011. Memenangkan Pasar Dengan Pemasaran Efektif Dan Profitabel. Jakarta: PT Gramedia Pustaka Utama

Faradina, Anissa, Fara, Satrio Budhi. 2016. Pengaruh Promosi dan Kualitas Pelayanan Terhadap Kepuasan Pelanggan Pada Rumah Cantik Alamanda. Jurnal Ilmu dan Riset Manajemen. Vol. 5, Nomor 7, Juli 2016. ISSN: 2461-0593.

Handoko, Bagus. 2017. Pengaruh Promosi, Harga dan Kualitas Pelayanan Terhadap Kepuasan Pelanggan Pada Titipan Kilat JNE Medan. Jurnal Ilmiah Manajemen dan Bisnis. Vol. 18 No.1, 2017, Hal.61-72. ISSN: 1693-7619.

Hutabarat, Jemsley dan Martani Huseini. 2006. PFI, Manajemen Strategik Kontemporer. Jakarta: PT. Elex Media Komputindo

Komariah, Kokom. 201. Pengaruh Kualitas Produk, Fasilitas Produk, dan Harga Terhadap Kepuasan Konsumen Pada Perumahan Griya Rahmani 2 'Jatisutera' di Wilayah Jakarta Selatan (studi Kasus : CV. Bangun Mandiri Property). Skripsi S1, Ekonomi Manajemen Universitas Gunadarma. Depok Jawa Barat. 
Kotler dan Keller. 2009. Manajemen Pemasaran. Jilid I. Edisi ke 13 Jakarta: Erlangga

Lenzun, Jessica. J, Massie James D.D, Adare Decky. 2014. Pengaruh Kualitas Produk, Harga, Promosi Terhadap Kepuasan Pelanggan Kartu Prabayar Telkomsel. Jurnal EMBA. Vol.2 No.3 September 2014, Hal. 1237-1245. ISSN: 2303-1174.

Premayani, N. W. W., \& Yoga, G. A. D. M. (2019). Pengaruh Kewajaran Harga Dan Kualitas Produk Terhadap Kepuasan Konsumen Wina Rumah Kebaya. WIDYA MANAJEMEN, 1(2), 113-157. https://doi.org/10.32795/widyamanajemen.v1i2.360

Razak, Ismail. 2019. Pengaruh Kualitas Produk Terhadap Kepuasan Pelanggan. Jurnal Manajemen Bisnis Krisnadwipayana. Vol.7 No.2 Mei-Agustus 2019. p-ISSN: 2338-4794. e-ISSN: 25797476.

Sari Jaya Buah, UD. Laporan Biaya Promosi. 2017-2019. Badung

Sari Jaya Buah, UD. Laporan Jumlah Penjualan. 2017-2019. Badung

Nazir, Moh. 2014. Metode Penelitian. Bogor: Ghalia Indonesia.

Sugiyono. 2017. Metode Penelitian Kuantitatif, Kualitatif, Dan R\&D. Bandung: Alfabeta.

Tjiptono, Fandy. 2014. Pemasaran jasa-prinsip, penerapan dan penelitian. Yogyakarta: Andi Offset

Umar, Huesin. 2013. Riset Pemasaran \& Perilaku Konsumen. Jakarta: PT. Gramedia Pustaka Utama. 